\title{
Review Article \\ Review on Vertical Twin-Roll Strip Casting: A Key Technology for Quality Strips
}

\author{
Seshadev Sahoo \\ Department of Mechanical Engineering, Institute of Technical Education and Research, Siksha 'O' Anusandhan University, \\ Khandagiri Square, Bhubaneswar 751030, India
}

Correspondence should be addressed to Seshadev Sahoo; seshadevsahoo@soauniversity.ac.in

Received 21 March 2016; Revised 21 June 2016; Accepted 11 July 2016

Academic Editor: Menahem Bamberger

Copyright (C) 2016 Seshadev Sahoo. This is an open access article distributed under the Creative Commons Attribution License, which permits unrestricted use, distribution, and reproduction in any medium, provided the original work is properly cited.

\begin{abstract}
Nowadays near-net-shape casting technology is an important area of research in the iron and steel industry. Among different kinds of near-net-shape casting process, twin-roll casting process has received much attention among researchers. Twin-roll casting (TRC) has been the subject of extensive research, not only to develop the technology but also to achieve an understanding of microstructural evolution and to produce quality strips. The main issues concerning the design and operation of twin-roll casters are metal-mold heat transfer, metal delivery system, and their possible effects on the solid shell formation and characteristics of the strips. The present review gives an idea about the process aspect, modeling, and quality issues in vertical twin-roll strip casting process and helps to improve the design of twin-roll strip caster.
\end{abstract}

\section{Introduction}

Twin-roll strip casting process is a near-net-shape casting technology, for the production of thin strips having thickness of about $0.1 \mathrm{~mm}$ to $6.0 \mathrm{~mm}$. This process produces thin strips directly from the liquid metal by combining casting and rolling in a single step. This process provides better control over the microstructure and mechanical properties of the cast strip. The twin-roll strip casting process is very simple, but there are several complex phenomena like fluid flow, heat transfer, and solidification involved in the process. The process of twin-roll strip casting is dynamic and quick and occurs at high temperature. The success of twin-roll strip casting process has led to the elimination of the hot rolling process and made the manufacturing of strips, which are difficult to hot-roll [1]. Depending on the strip thickness, the solidification rates in this process vary typically from $10^{2} \mathrm{~K} / \mathrm{s}$ to $10^{4} \mathrm{~K} / \mathrm{s}$ and it is well below the rapid solidification range $\left(10^{5} \mathrm{~K} / \mathrm{s}\right.$ to $\left.10^{6} \mathrm{~K} / \mathrm{s}\right)$. Strip casting using the twin-roll strip caster has many advantages like low equipment cost, low running cost, energy saving, space saving, and so forth [2]. However, it has disadvantages too; one of the major disadvantages is low productivity [3].
The control of microstructure of strip is of primary importance in twin-roll strip casting process, because further significant modification of the microstructure, on which the properties of the strip depend, may not be possible. The microstructure of the strip depends on cooling rate and solidification front speed at various locations in the strand, which in turn depends upon the casting parameters like casting speed, roll gap, superheat of liquid metal, roll force, roll materials, and so forth. Therefore, one needs to identify the specific combination of design and process parameters that will result in the desired microstructure of the strip.

\section{Strip Casting Process and Its Classification}

Near-net-shape casting process has stimulated increasing efforts for the production of flat products, in terms of both investment and operating costs and greater flexibility and possibility of better material properties in comparison with conventional continuous casting technology. With the aim of achieving good surface quality and high productivity, different types of near-net-shape casting (NNSC) processes have been developed, which was also known as strip casting (SC) process. 


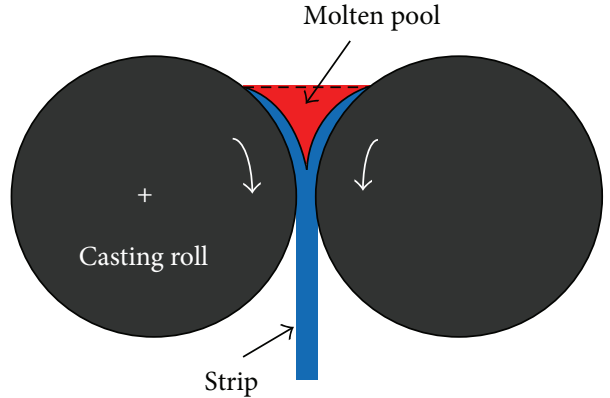

(a)

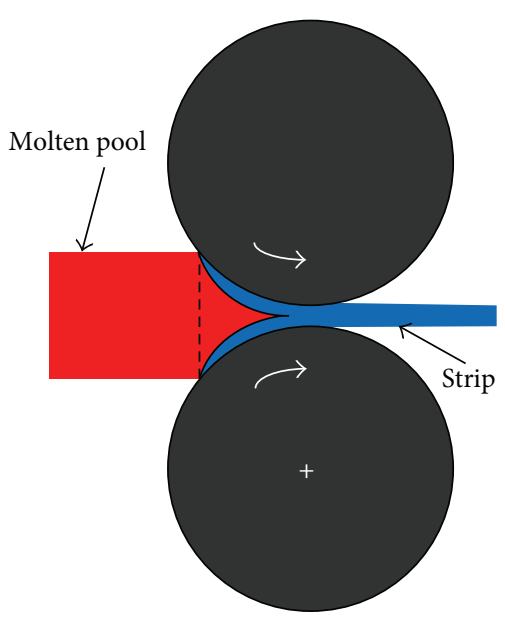

(b)

Figure 1: (a) Vertical twin-roll strip caster. (b) Horizontal twin-roll strip caster.

Strip casting process is the category of NNSC process, which produces thin strips directly from the liquid metal. The principle of strip casting technology is to solidify the liquid metal when it comes in contact with the rotating mold and produce thin strips with the desired thickness. This process was first developed by Bessemer [4]. It has become one of the most interesting technologies in the ferrous and nonferrous industry in the last decade. Driving forces for the developments of this technology are as follows:

(i) Reduction of Steps. Reduction of rolling steps leads to labour and energy savings as compared to conventional casting route $[2,5]$.

(ii) Lower Energy Consumption. With the shortening of production steps, the requirement of energy becomes less.

(iii) Reduction of Investment Cost. With the reduction of processing steps, the production cost is reduced [6].

With the abovementioned advantages of the process, the quality of the product which is produced by the strip casting process is an important issue that has to be considered. Choo et al. [7] and $\mathrm{Ha}$ et al. [8] found that the main problem related to the strip quality was the presence of defects on the strip surface such as transverse cracks, longitudinal cracks, wrinkles, and cavities. During the last few decades, many processes of strip casting have been developed, but they all share in common the fact that liquid metal is fed into the caster and then it solidifies in direct contact with the moving substrate. Finally, the casting emerges from the caster directly as a solidified strip. Two major types of strip casting set-ups were found:

(i) Single-roll caster.

(ii) Twin-roll caster.

(i) Single-Roll Caster. Single-roll caster was first developed in United States based on amorphous strip casting technology. It is based on the principle that the strips are produced by using a rotating substrate. The strips produced in this method have two different surfaces, a roll side surface and a free surface. In this method the rate of heat extraction and to control the shape of strip are insufficient which results in deterioration of shape and quality of the strip.

(ii) Twin-Roll Caster. Twin-roll caster was based on the concept of Bessemer [4], where the molten metal is fed into the roll gap. It has higher heat extraction capacity than that of single-roll caster. A thicker strip can be cast and qualities of both sides of the strip surfaces are the same in this caster.

These processing techniques were investigated by various researchers. However, for the production of thin strips, twinroll casting has become the leading technology which has received much attention nowadays.

\section{Twin-Roll Strip Casting Process}

The twin-roll strip casting process is based on the concept originally proposed by an English engineer, Sir Bessemer [4]. This process involves feeding of molten metal between two counterrotating rolls, which act as the cooling and deformation elements, to solidify the molten metal into sheet. The characteristics of the process that make it so attractive are as follows:

(i) Friction Free Casting. Roll and solidified metal move approximately at the same velocity.

(ii) Lubricating slag is not necessary, which increases the heat flux at the metal-roll interface and leads to higher rate of solidification.

(iii) Combination of casting and rolling is in a single operation.

Twin-roll strip casters can consist of either equal sized rolls or unequal sized rolls. These rolls may be arranged horizontally, vertically, or inclined $[9,10]$. According to the direction of casting, the twin-roll strip caster is divided into two types which are shown in Figure 1. These are 


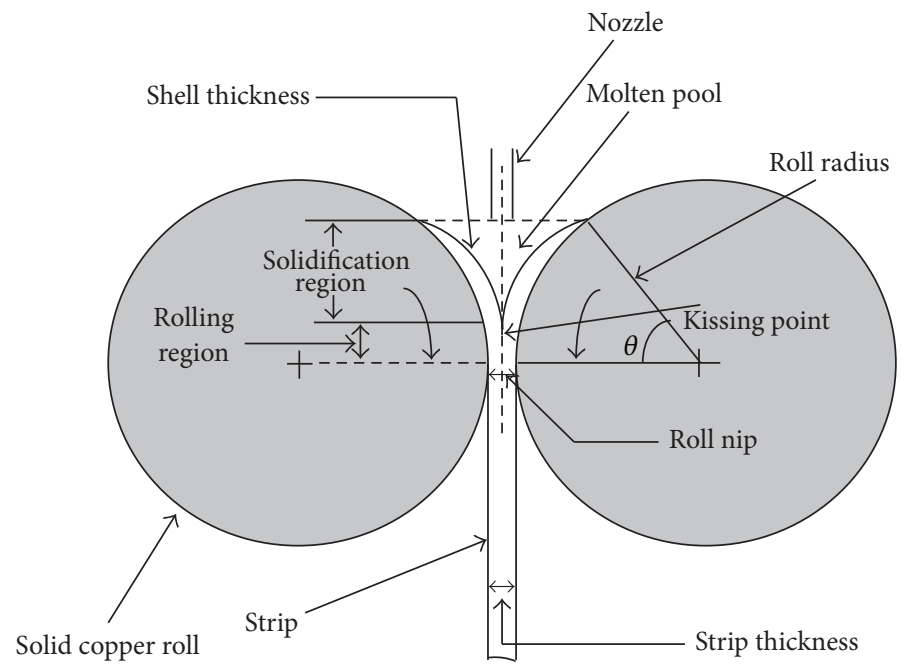

FIGURE 2: Schematic diagram of vertical twin-roll strip caster.

TABLE 1: Comparison of horizontal twin-roll strip caster and vertical twin-roll strip caster.

\begin{tabular}{|c|c|c|}
\hline Type & $\begin{array}{l}\text { Horizontal } \\
\text { twin-roll strip } \\
\text { caster }\end{array}$ & $\begin{array}{l}\text { Vertical twin-roll } \\
\text { strip caster }\end{array}$ \\
\hline Lubricant & Use & No-use \\
\hline Casting speed & $1-15 \mathrm{~m} / \mathrm{min}$ & $30-150 \mathrm{~m} / \mathrm{min}$ \\
\hline Roll force & $>1 \mathrm{KN} / \mathrm{mm}$ (width) & $\begin{array}{l}<0.5 \mathrm{KN} / \mathrm{mm} \\
\text { (width) }\end{array}$ \\
\hline Strip thickness & 4-7 mm & $2-4 \mathrm{~mm}$ \\
\hline Cooling rate & Low & High \\
\hline
\end{tabular}

(1) vertical twin-roll strip caster (VTRSC),

(2) horizontal twin-roll strip caster (HTRSC).

In vertical twin-roll caster, the two rolls are aligned horizontally and the direction of casting is in vertical direction, whereas in horizontal twin-roll caster, the two rolls are aligned vertically and the direction of casting is in horizontal direction. Table 1 shows the comparison between the horizontal twin-roll strip caster and the vertical twin-roll strip caster [11].

The ultimate goal in twin-roll strip caster is to cast thinner, wider, and faster with minimizing the macro- and microdefects on the strip surface. Casting wider and faster directly increases the productivity, while casting at a reduced gauge is an advantage in a way that it can save subsequent cold rolling steps. Based on the comparison of HTRSC and VTRSC, the most typical configuration used in strip casting is so called vertical twin-roll strip caster.

3.1. Principles of Vertical Twin-Roll Strip Caster. The vertical twin-roll strip caster is composed of two equal diameter counterrotating rolls. The rolls are normally made of high thermal conductivity of copper/steel alloys. Their axes of rotation are located in the same horizontal plane. The main equipment used within this process is the crucible, the tundish, the molten metal feeding system (nozzle), and the rolls. In this process, the liquid metal is supplied from the tundish through a nozzle into the wedge-shaped region formed by the two counterrotating rolls. When the superheated liquid metal comes in contact with the moving rolls, solidification starts with the extraction of heat from the liquid metal to the roll surface and a thin solidified shell is formed on each of the roll surfaces. With the continuous extraction of heat through the moving rolls, the solidified shells gradually grow in thickness. Finally, the two solidified shells contact with each other and weld together at the nip of the rolls (minimum distance between the rolls) and the material exits from the caster in the form of a solidified strip [12]. A more detailed schematic view of a vertical twin-roll strip caster is presented in Figure 2.

\subsection{Process Parameters and Their Effect on Strip Charac-} teristics. The microstructure and mechanical properties of the solidified materials depend on solidification behavior. The solidification mechanism in twin-roll strip caster can be controlled by different process parameter. When the liquid metal leaves the nozzle and touches the roll surface, solidification usually begins against the two rolls by losing heat from the liquid metal to the roll surface, and as a result, the formation of two shells grows in thickness and they continue to move forward through the melt pool and finally contact with each other at the roll nip (minimum distance between the two rolls) [2]. The conversion from liquid to solid includes a semisolid region, that is, mushy zone. When the solidifying metal has reached adequate strength, the material experiences a degree of hot working before leaving the roll bite, which allows changes in the geometrical properties and microstructure of strip. This allows a better adhesion of the two shells to each other, avoiding voids and porosity in the center of the strip. So the twin-roll 
strip casting process combines solidification and deformation into a single process. The solidification phenomena in twinroll strip casting process depend on the following process parameters of twin-roll strip caster:

(i) Diameter of the roll.

(ii) Roll material.

(iii) Casting speed.

(iv) Roll gap.

(v) Metal delivery system.

(vi) Metal-roll heat transfer coefficient.

3.2.1. Roll Material. The solid shell forms on the surface of the rolls and the heat transfer between the rolls and the liquid metal primarily depends on the roll material. In order to increase the solidification rate, the roll material having higher thermal conductivity is used, which allows higher cooling rate and lower surface temperature $[11,13]$. Typically, the rolls are made of steel or copper. The material of the rolls has a significant impact on the roll speeds that can be achieved due to the fact that the material of the roll dictates the heat transfer coefficient at the interface between the molten metal and roll surface. The higher the heat transfer coefficient, the more the heat that can be extracted in a shorter period of time, which in turn results in the ability to cast at higher speeds [14]. Thus, the roll material directly impacts the production rate of cast strip in the twin-roll strip casting process. Haga et al. [11] found that, by using the copper roll in twin-roll strip caster as a roll material, the twin-roll caster was able to cast at speeds 10 times higher and reduces the thickness of the strip to half than the strip prepared by continuous casting. The microstructure of the strip was also better.

3.2.2. Diameter of Roll. With increase in roll diameter, the contact length between the rolls and the liquid metal increases. This will increase the heat transfer rate and solidification becomes faster. The vertical twin-roll strip casting process can achieve cooling rates in the range of $100^{\circ} \mathrm{C} / \mathrm{s}$ to $1000^{\circ} \mathrm{C} / \mathrm{s}$ [15]. The cooling rate is greatly dependent on the roll speed and the roll material.

3.2.3. Casting Speed. Control of the casting speed is necessary to control the incoming flow of the liquid metal to enable stable casting operation in twin-roll strip caster, which will affect the solidification phenomena. The casting speed has direct effect on the position of the solidification end point and the roll separating force. If the solidification end point is moving below the kissing point of the twin-roll caster, this results in bulging, cracks, and reduction in thickness of the strip [16]. Sahoo et al. [17] studied the effect of casting speed on microstructure of Al-33Cu alloy and they found that, with increase in casting speed, the microstructure of the strip becomes finer and interlamellar spacing in $\mathrm{Al}-33 \mathrm{Cu}$ eutectic structure decreases.

3.2.4. Metal Delivery System. The metal delivery system has a direct impact on the solidification behavior. The metal delivery system consists of ladle, device to control the flow rate and the nozzles. For the conservation of mass, the metal delivery system has to supply the amount of liquid, which will match with the amount of liquid that exits from the roll nip. In other words, the supply of liquid metal has to be such that the input and output mass flow rates match. If the metal delivery system is not properly designed, this affects the flow behavior of the liquid metal in the molten pool, which causes free surface fluctuation [18], excessive recirculation of the liquid metal in the molten pool [19], and so forth. The free surface fluctuation on the pool surface and recirculation in the molten pool will affect the solidification phenomena, which results in defects on the strip surface such as (i) thickness deviation caused by pool level fluctuation [20] and (ii) strip roughness which can be worsened by instability in the meniscus shape and so forth [12].

3.2.5. Metal-Roll Heat Transfer Coefficient. The interfacial heat transfer coefficient between the rolls and the liquid metal plays a crucial role in determining the overall productivity of the TRSC process and the quality of the product. The interfacial heat transfer coefficient depends on several parameters, that is, casting speed, the conductivity of the roll material, the surface roughness of the rolls, the type of the alloy used in the casting, and the use of lubricant of the roll surface [21, 22]. It is desired that the rolls should have a high thermal conductivity value to remove the heat from the molten metal as quickly as possible. The surface of the rolls should be as smooth as possible to minimize the air gap formation between the initially solidified strip and the roll surface, which will increase the heat transfer from the liquid metal to roll surface.

Since the process includes both solidification and deformation, the control of the process is inherently difficult. There are many process parameters which interact with each other. The control of solidification condition by controlling the process parameters is the fundamental requirement to prevent or significantly delay the onset of macro- and microstructural defects on the strip materials.

\section{Investigation on Vertical Twin-Roll Strip Casting Process}

The analysis of twin-roll strip casting processes requires the solution of thermal and flow patterns, where the solidification is an important operational variable, which affects the quality of the final products.

4.1. Numerical Investigation. The first attempt to model heat transfer and fluid flow of liquid and solid in a twin-roll caster was made by Miyazawa and Szekely [23]. These authors reported the two-dimensional uncoupled fluid flow and heat transfer results for a pure aluminum system, after making a number of simplifying assumptions. Laminar flow was considered in the liquid pool and plastic flow was assumed in the solid shell, when the solidification occurred before the roll nip. The model was applied to casting pure aluminum where the existence of mushy zone was not considered. Based on 
these assumptions, a steady state two-dimensional velocity and temperature profile in the solid and liquid region were obtained. In terms of fluid flow, a recirculating flow was obtained in the liquid region which increased with increase in the flow rate. A two-dimensional numerical model of twinroll continuous casting similar to those of Miyazawa and Szekely [23] was developed by Saitoh et al. [24]. They studied the heat transfer and flow characteristic in both the solid and liquid phases of metal and solved the governing equations separately using finite difference method.

A two-dimensional steady state mathematical model of coupled turbulent fluid flow, heat transfer, and solidification for a vertical twin-roll caster was developed by Murakami et al. [25]. In their formulation, they were considered both natural and forced convection along with turbulent flow. The mushy zone was modeled by means of the enthalpy-porosity technique. With this approach the author analyzed the effect of inlet flow on the formation of solid shell in a twin-roll caster. After Murakami et al. [25], a mathematical model based on finite volume method was developed by Lee [26] to predict the flow field and solidification phenomena in the region of rotating bank during the twin-roll casting of molten steel (SUS304) at $1.41 \mathrm{~m} / \mathrm{s}$ (18 rpm roll) speed. In their model, they predicted the solidification end point which provides valuable information on the thermal stress of the cooling rolls and roll separating force. Hwang and Kang [27] developed a steady state two-dimensional heat transfer and fluid flow model for twin-roll strip casting of stainless steel and $\mathrm{Pb}-\mathrm{Sn}$ alloy by using finite element approach. Heat generation due to the viscous work and plastic flow were taken into account and it was found that viscous work had minor effect on the temperature profiles. The results of their simulations showed only qualitative agreement with the experimental work developed by Saitoh et al. [24]. Following the same guidelines of the study presented by Murakami et al. [25], Seyedein and Hasan [28] also applied boundary fitted coordinates to model a twodimensional steady state turbulent fluid flow, heat transfer, and solidification in the wedge-shaped cavity of a twin-roll strip caster. They improved the numerical scheme adopted in the solution of the governing equations; however, in their first model they did not include solidification phenomena and in the later model they considered the solidification phenomena along with temperature independent properties of liquid metal and having casting speed $1 \mathrm{~m} / \mathrm{s}$ (16 rpm). Chang and Weng [29] used finite element method to model the twin-roll casting. They coupled the fluid flow and heat transfer in this model and incorporated interface search scheme on local transformation technique to reduce the complexities of the model, which helped to easily handle the different materials behavior and discontinuity of material properties along different phases during simulation. A threedimensional fluid flow, heat transfer, and solidification model was developed by Guthrie and Tavares [30] to study different metal delivery systems for twin-roll casting using METFLO code. These simulations applied to a pilot caster being studied in Canada with roll radius $0.30 \mathrm{~m}$ producing steel strips with thickness ranging from $4 \mathrm{~mm}$ to $7 \mathrm{~mm}$ at a relatively low casting speed of $0.06 \mathrm{~m} / \mathrm{s}$ to $0.2 \mathrm{~m} / \mathrm{s}$ ( $5 \mathrm{rpm}$ to $7 \mathrm{rpm}$ ).
Santos et al. [31] developed a numerical model to simulate the solidification and heat transfer in the strip casting process having casting speed of $0.03 \mathrm{~m} / \mathrm{s}(14 \mathrm{rpm})$ using the finite difference technique. The model helps in design and control of the twin-roll experimental system. The author introduced a heat transfer coefficient between liquid metal and roll instead of constant temperature $(290 \mathrm{~K})$ boundary condition used by Saitoh et al. [24]. A two-dimensional finite element method (FEM) was formulated by Gupta and Sahai [32] to simulate the fluid flow, heat transfer, and solidification in the twin-roll strip casting having casting speed of $0.77 \mathrm{~m} / \mathrm{s}(50 \mathrm{rpm})$. They used the temperature dependent viscosity of liquid metal but the remaining properties of the materials were not varied with temperature. They found that the casting speed and melt-roll heat transfer coefficient were the main parameters to affect the strip thickness, whereas melt superheat showed a little effect. A numerical investigation of the characteristics of the fluid flow and heat transfer in a wedge-shaped pool during the strip casting of stainless steel at a casting speed of $0.3 \mathrm{~m} / \mathrm{s}$ (16 rpm) was investigated by Kim et al. [33]. They studied the effects of roll gap and different nozzle design on the flow pattern of melt and on the temperature distribution. From their model, they developed a fundamental understanding of the design of the twin-roll casting system.

The numerical investigation of turbulent fluid flow and solidification in twin-roll caster was studied by Kim et al. [34]. The authors studied the influence of various process parameters like nozzle type, roll gap thickness, metal superheat, and so forth on the solidification phenomena in the wedgeshaped molten pool and optimized the process parameters from simulation for casting of quality strips. A twin-roll casting industrial process was analyzed by Cruchaga et al. [35] using FEM to study the coupled fluid flow and phase change phenomena. In this work, the author examined the influence of different roll speeds, metal-roll heat transfer coefficients on flow, and heat transfer and solidification patterns and found that the temperature of the strip at the exit section is higher for higher rolling speed and lower metalroll heat transfer coefficient. An integral three-dimensional model of fluid flow and heat transfer during twin-roll strip casting was developed by Miao et al. [36] using FEM and they studied the effect of different process parameters on the fluid flow and temperature field. Their model helped in designing the nozzle and controlling the process parameters of twin-roll casting process. A numerical investigation of the characteristics of the fluid flow and heat transfer in a pool region was examined by Bae et al. [37] and Cao et al. [38], having the casting speed varied from $0.05 \mathrm{~m} / \mathrm{s}$ to $0.52 \mathrm{~m} / \mathrm{s}$ ( 4 to $20 \mathrm{rpm}$ ). The effects of casting velocity and pool height on flow pattern and solidification were studied to obtain good quality of strips. From their model they numerically found that the position of the solidification end point depends on the process parameters and the location and size of the vortex in the pool region have big influence on the cooling rate during the twin-roll casting process. Zhang et al. [39] developed a FEM model to simulate twinroll strip casting process at $0.52 \mathrm{~m} / \mathrm{s}(20 \mathrm{rpm})$ casting speed and studied the influence of the process parameters, that is, pouring temperature and height of liquid level to control the 
twin-roll strip casting process and improve the quality of the strips. The CFD model developed by Zeng et al. [10] focused on a better understanding of the melt flow characteristics and thermal exchanges during the rapid solidification of the $\mathrm{Mg}$ melt during the twin-roll casting. They also highlighted the effect of casting speed and the gauge (twin-roll gap opening) on the melt flow and solidification. They used constant thermophysical properties like density, specific heat, latent heat, thermal conductivity, and viscosity and measured the temperature of the casting strip both from the model and from the experiment and found that the calculated results for varying casting speeds are in good match with experimental determination. Fang et al. [40] simulated the temperature field of the strip in twin-roll casting method and studied the variation of temperature with different roll radii and roll gaps. They found that, at smaller roll radius and larger roll gap, the freezing point is close to the exit. In their model they simulated the model having casting speed of $0.5 \mathrm{~m} / \mathrm{s}$ to $1.33 \mathrm{~m} / \mathrm{s}$ (10 to $43 \mathrm{rpm}$ ) and they did not consider the temperature dependency of thermophysical properties. A three-dimensional mathematical model was developed to simulate turbulent fluid flow, heat transfer, and solidification in the pool of a twin-roll strip caster having casting speed of $1 \mathrm{~m} / \mathrm{s}$ [41]. A Darcy-porosity approach was used to study the fluid flow within the mushy zone in the pool. The effects of the heat transfer coefficient and permeability constant on the flow and solidification phenomena were studied and it was found that the heat transfer between the rolls and the solidifying metal has a big influence on the location of the solidification end point and the permeability constant was a key factor to understand the flow behavior. However, in the model they considered constant thermophysical properties.

Zhao et al. [42] developed a mathematical model of twinroll casting of magnesium alloy. In their model, the authors considered the heat conduction coefficient of roll and strip was constant and the thermophysical parameters were the function of temperature but the casting speed was limited to $0.03 \mathrm{~m} / \mathrm{s}$ to $0.06 \mathrm{~m} / \mathrm{s}$ ( $2 \mathrm{rpm}$ to $3 \mathrm{rpm})$. Li et al. [43] developed a steady state finite element model to study the effect of processing parameters like casting speed and casting temperature on the freezing point position of 304 stainless steel during twin-roll strip casting process and found that the position of freezing point is decreased with increase in casting speed and casting temperature. With the use of the model, the authors optimized the casting speed and casting temperature for producing quality strips. But, in their model, they also have considered temperature independent thermophysical properties and casting speed of $0.5 \mathrm{~m} / \mathrm{s}(16 \mathrm{rpm})$. A thermal-fluidstress model has been developed by Hadadzadeh and Wells [44] for AZ31 magnesium alloy TRC process using the finite element method (FEM). This model is taking simultaneously the transport phenomena to stress-strain development in the cast strip and analyzed the effect of setback distance on the thermomechanical behavior of the AZ31 strip during TRC. Shoudong and Jingchao [45] developed a micromodel to simulate the solidification structure of twin-roll casting of $\mathrm{Al}-4.5 \% \mathrm{Cu}$. Based on the micromodel they studied the effect of heat transfer coefficient and pouring temperature on the strip solidification microstructure and found that, with increase in pouring temperature of the liquid metal, the grain size increases. Hadadzadeh et al. [46] developed a finite element model for twin-roll casting process to predict the fluid flow, heat transfer, and stress development in the cast strip. A mathematical model was developed by Sahoo et al. [17, 47] for high speed twin-roll strip casting process having casting speed $>1 \mathrm{~m} / \mathrm{s}$. The model also predicts the influence of processing parameters like casting speed, initial pouring temperature, and roll gap on solidification behavior and found that at high casting speed a layered composite strip is produced. Numerical simulation has been done by Sahoo and Ghosh [48] to calculate the transient length of the strip during starting of twin-roll strip casting. Their study helps to determine the transient length of the strip as well as calculate the time required for steady state condition achieved in casting process. Lee et al. [49] carried out a two-dimensional finite element analysis on a horizontal twin-roll casting of A7075 aluminum strips and studied the effect of roll speed and found that, with increasing in casting speed, the solidified shell thickness increases. Park [50] developed a finite element model to study the cladding process of $\mathrm{Mg}$ and $\mathrm{Al}$ alloys in twin-roll strip caster. From their investigation, they found that the interfacial heat transfer coefficient is main factor for the cooling rate which affects the cladding processes.

\subsection{Experimental Investigation. Numerous experimental} works have been carried out to study the development of twin-roll strip casting process and casting of different alloys. A thin strip caster has been developed by Shibuya et al. [51] which consists of twin cooling rolls to cast $4.5 \mathrm{wt} \% \mathrm{Si}-\mathrm{Fe}$ alloy having $0.2 \mathrm{~mm}$ to $1 \mathrm{~mm}$ in thickness. A hot model Bessemer type twin-roll caster was established by Fiedler et al. [18] to investigate the effect of the key components of this casting machine on product quality and properties of directly cast steel strips. Cook et al. [52] developed the twin-roll casting process to overcome some of the shortcomings of the traditional process to increase the productivity and casting of wide range of alloys and avoid the sticking problem. But in this development they achieved the casting speed up to $0.25 \mathrm{~m} / \mathrm{s}(12 \mathrm{rpm})$. To gain better understanding of the influence of technological parameters like geometry of nozzle slot, roll sleeve thickness, diameter, length of roll, and so forth on the cross-sectional shape of the strip, a laboratory size twin-roll casting process was investigated by Zapuskalov and Vereschagin [53]. Different types of twin-roll casters like vertical twin-roll caster [11], melt ejection twin-roll caster [13], and melt drag twin-roll caster [16] were developed to produce aluminum alloy strips by varying the casting speeds from $0.33 \mathrm{~m} / \mathrm{s}$ to $2.5 \mathrm{~m} / \mathrm{s}$ (22 rpm to $160 \mathrm{rpm})$. In these casters copper rolls were used and lubricant was not used in order to increase the casting speed. Low superheat casting was carried out in order to improve microstructure and mechanical properties of the strips compared to conventional techniques. Haga and Suzuki [13] studied the microstructure of as-cast strips of A356 aluminum alloy prepared by continuous casting followed by rolling and twin-roll strip casting. The microstructure shows that some defects existed on the surface of the strip which were prepared by continuous casting as compared to 
twin-roll casting. In both the processes, the microstructure and property vary with the process parameters. As the process parameters like casting speed, metal superheat, and so forth vary, the cooling rate varies which directly affects the microstructure and properties of the strip. As the cooling rate is more in twin-roll caster as compared to continuous casting, the microstructure and properties of strip are better. This is the case for different alloys like steel, $\mathrm{Mg}$, and $\mathrm{Al}$ alloys [54-57]. Wang et al. [58] investigated the effect of process parameters of twin-roll caster on microstructure formation of aluminum alloys and found that the casting speed and roll gap are two main factors for microstructure formation as they directly control the cooling rate.

A tandem twin-roll caster with vertical type was fabricated and assembled successfully which can cast clad strips. Multiple layers of clad strip of different alloys have been cast by using vertical type tandem twin-roll caster at only one process. The interface between the strips was clear and flat. The strips were bonded firmly, which gives better microstructure and mechanical properties [59]. High-strength aluminum and magnesium alloys were cast in twin-roll caster by several authors $[58,60,61]$. From their study, it was observed that the process parameters were main important factors for obtaining a quality strip. From the microstructural observation, they found that the microstructure of the strip has smaller grains with better mechanical properties as compared to strip prepared by continuous casting.

\section{Quality of the Cast Strips}

The main benefit of TRSC process is based on the reduction of large number of processing steps and production costs. However, TRSC process produces thin strips where good surface quality is required, since only limited secondary processing is available to modify these parameters [1]. Cracking during subsequent rolling and forming may be caused by internal and external defects. The ability to prevent the formation of defects or at least postpone their appearance to higher productivities is a clear industrial challenge [62].

In twin-roll strip casting process, the quality of the strips is an important issue. Regarding the surface quality of the strips, Hwang et al. [63] found that the main defects in twinroll cast strips are longitudinal cracks, transverse cracks, and small depressions or wrinkles.

The formation of longitudinal cracks in the strip surface produced by twin-roll strip casting process has been studied by several groups of researchers. Longitudinal cracks occur in the center part of the strip surface.

It is caused due to

(i) uneven heat transfers across the strip width,

(ii) uneven contraction strain generated due to uneven cooling,

(iii) crack which is formed resulting from the build-up of heavy localized tensile strain.

Delay in solidification occurs due to the uneven heat transfer across strip width which is subjected to tensile strain in the interior of the strip, while a compressive strain appears at the surface. This tensile strain in the surface region with delayed solidification is responsible for the formation of crack. The uneven heat transfer occurred due to (i) free surface fluctuation, (ii) nonuniform temperature inside the molten pool, and (iii) variation of heat transfer across the roll width.

Transverse cracks occur randomly and especially in the initial stage of casting operation which is caused by the fluctuation of the free surface of the molten pool $[18,63]$. Transverse cracks also related to the hot rolling of the strip before it leaves the roll gap. This occurs when the two solidification fronts forming on the surface of the rolls meet before the roll nip. So an adequate combination of casting speed and roll separating force for certain strip thickness eliminates the cracks.

For a given roll gap, an increase in casting speed induces rapid decrease of roll separating force. This may suggest that solidification is completed at the roll nip point. An increase in roll speed also causes a downward shift of the solidification end point, where the two solidification fronts meet and transverse cracks are found to be eliminated by controlling the roll separating force [18].

Mizoguchi et al. [64] found that the formation of surface wrinkles on twin-roll cast strips is due to locally delayed solidification, which is caused by thermal fluctuation on the roll-metal interface and the free surface fluctuation of the liquid metal. The free surface fluctuation causes an uneven heat transfer between the liquid metals to the roll surface which causes the surface defects in the as-cast strip. It suggests that these defects may be related to flow behavior and surface fluctuation in molten pool between the two rolls. The authors observed that free surface fluctuations depend on the casting speed. An increase in the casting speed decreases the free surface fluctuations and reduces the depth of the surface wrinkles of SUS304 steel.

Along with the longitudinal and transverse cracks, the other types of defects associated with the strip surface are surface bleeds [63], buckling [3], microsegregation [65], banded structure [66], edge cracking and ripple defects [67], and so forth which are formed due to low casting speed.

Based on the evidences mentioned above, the following are responsible for defect formation:

(i) Uneven heat transfers from the liquid metal to roll surface.

(ii) Free surface fluctuation in the molten pool.

(iii) Low casting speed.

To minimize the defects in the as-cast strip, it is necessary to reduce the free surface fluctuation in the molten pool and uneven heat transfer, which in turn can be minimized by increasing the casting speed. So this is the clear evidence of the importance of the high speed vertical twin-roll strip caster in producing quality strips. 


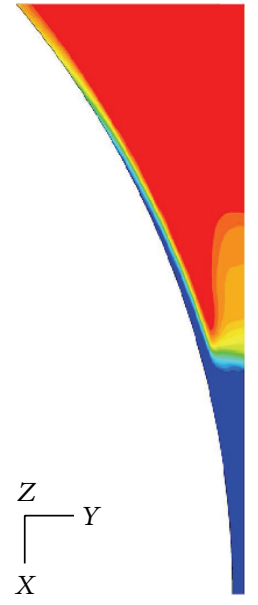

(a)

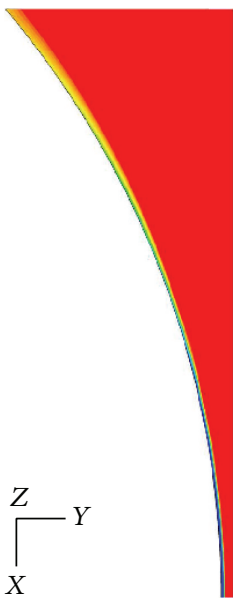

(e)

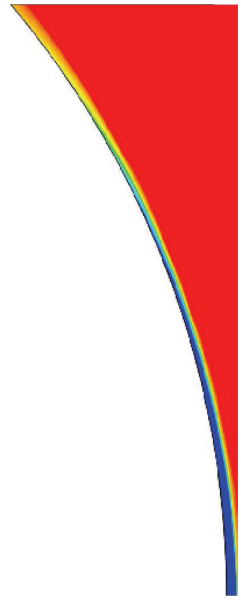

(b)

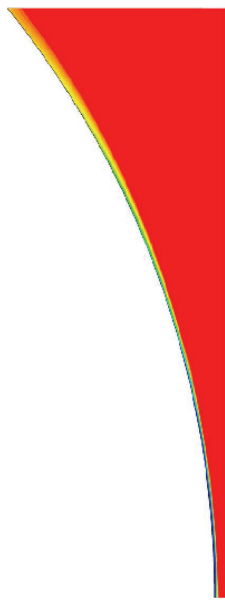

(f)

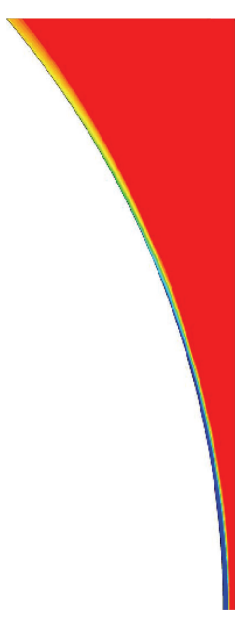

(c)

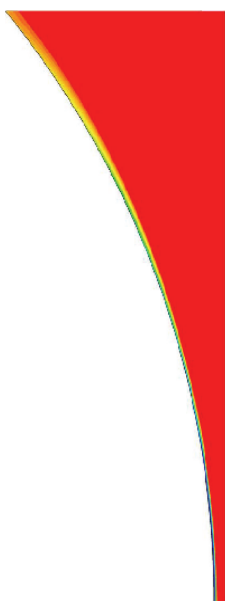

(g)

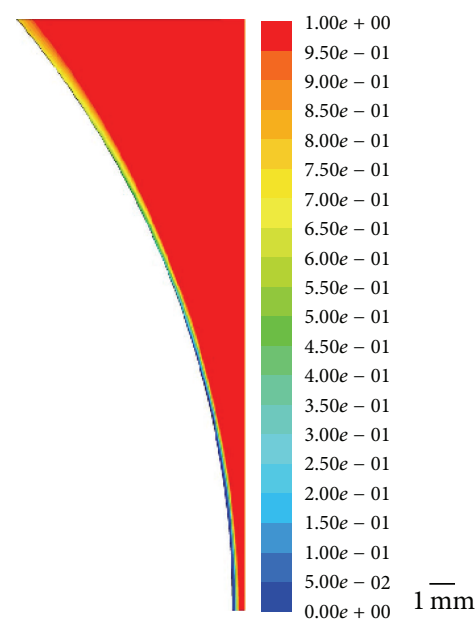

(d)

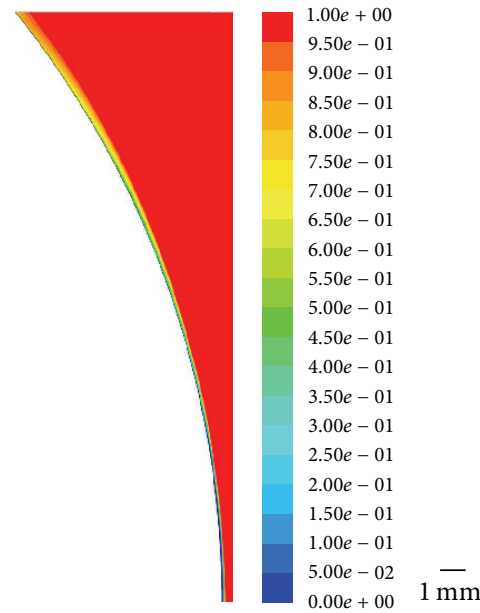

(h)

Figure 3: Solidification profile of Al-33Cu alloy at different casting speeds: (a) $0.0239 \mathrm{~m} / \mathrm{s}$, (b) $0.07979 \mathrm{~m} / \mathrm{s}$, (c) $0.3989 \mathrm{~m} / \mathrm{s}$, (d) $0.79 \mathrm{~m} / \mathrm{s}$, (e) $1.59 \mathrm{~m} / \mathrm{s}$, (f) $2.39 \mathrm{~m} / \mathrm{s}$, (g) $3.19 \mathrm{~m} / \mathrm{s}$, and (h) $3.98 \mathrm{~m} / \mathrm{s}$.

\section{Results of the Process Simulations with Experimental/Production Data}

Sahoo et al. $[17,47,68]$ simulated the high speed vertical twinroll strip caster using ANSYS platform. They studied the effect of different process parameters on solidification phenomena as well as microstructure of the strip.

6.1. Effect of Casting Speed. The simulations are carried out for casting of $\mathrm{Al}-33 \mathrm{Cu}$ strips having thickness of $2 \mathrm{~mm}$ in a twin-roll caster at different casting speeds, that is, $0.0239 \mathrm{~m} / \mathrm{s}$ to $3.98 \mathrm{~m} / \mathrm{s}(3-500 \mathrm{rpm})$. Figure 3 shows the solidification profile of $\mathrm{Al}-33 \mathrm{Cu}$ alloy at different casting speed. At very slow casting speed the liquid metal remains within the molten pool for a longer time. So the liquid metal gets enough time to transfer heat to the roll and the kissing point is located before the roll nip and the strip is rolled before it leaves. With further increase in the casting speed, fraction of liquid metal at the roll nip increases. At higher speeds liquid metal is left over. At higher casting speed contact time of liquid metal with the roll is less; hence the time provided for solidification of liquid metal is also less, which results in thinner solidified shell thickness at roll nip [17].

Figure 4 shows the as-cast microstructure of Al-33 wt.\% $\mathrm{Cu}$ alloy at casting speeds of 100-500 rpm. The microstructure of the solidified Al-33 wt.\% Cu strip was not uniform and two distinct zones were observed. At $100 \mathrm{rpm}$ roll speed the microstructure of the strip is not completely lamellar structure. It consists of both lamellar and wavy structure. At $100 \mathrm{rpm}$ roll speed, some part of liquid metal is solidified at the roll nip and some part is in liquid state. The liquid metal which is in direct contact with the roll surface forms lamellar structure due to the higher rate of heat transfer from the liquid metal to the roll surface and the remaining portion which is cooled later forms the wavy structure. As the roll speed is increased the fraction of liquid at the roll nip increases. By increasing the roll speed, the liquid metal gets less time to stay within the metal pool and the contact time between the molten metals with the roll surface is much less. The wide difference in the cooling rate/solidification 


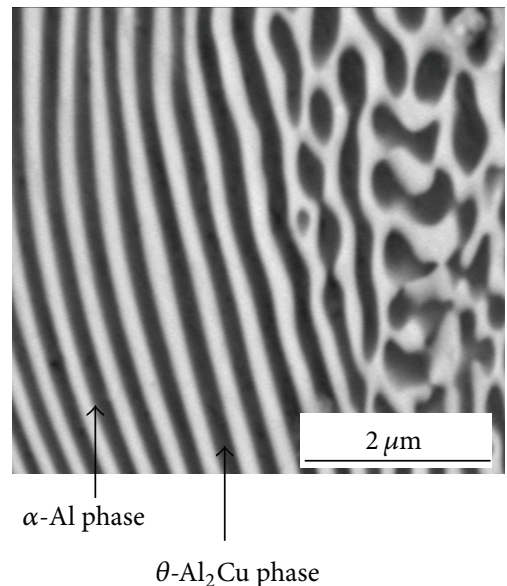

(a)
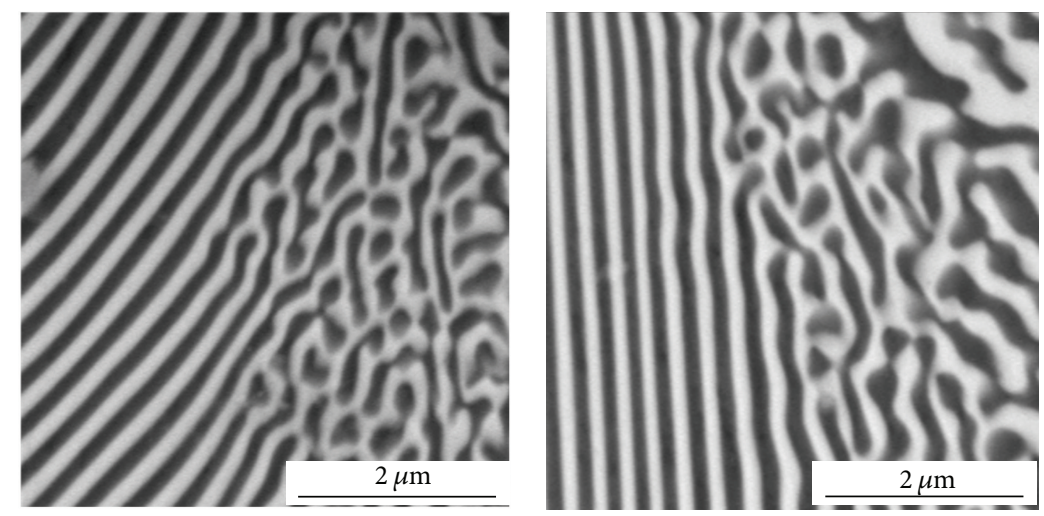

(b) (c)

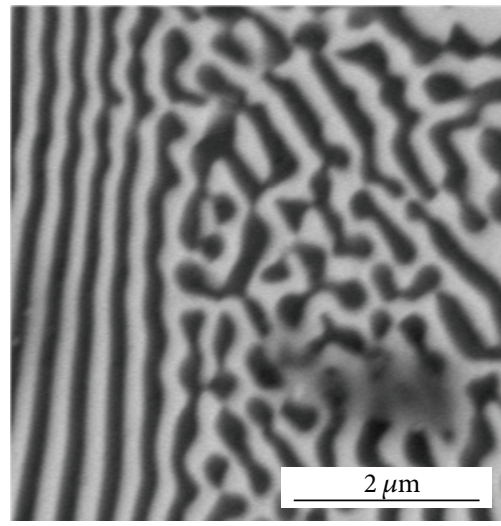

(d)

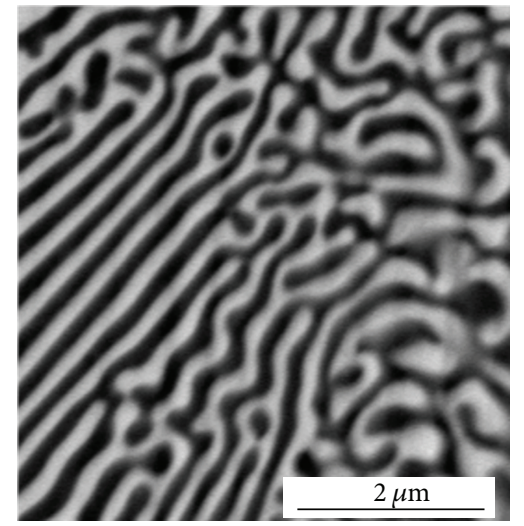

(e)

Figure 4: Microstructure of the as-cast sample along the thickness direction at different roll speeds: (a) $100 \mathrm{rpm}$, (b) $200 \mathrm{rpm}$, (c) $300 \mathrm{rpm}$, (d) $400 \mathrm{rpm}$, and (e) $500 \mathrm{rpm}$.

front speed is expected to give rise to distinct structure in the outer layer and inner portion of the cast Al-33 wt.\% Cu. By increasing the casting speed from $100 \mathrm{rpm}$ to $500 \mathrm{rpm}$ the width of the lamellar structure decreases and wavy structure increases. This is the effect of the difference in the speeds of solidification front $[17,69]$.

6.2. Effect of Liquid Metal Superheat. Numerical simulations are carried out to study the effect of liquid metal superheat on solidification of Al-33 wt.\% Cu alloy during high speed twin-roll casting. The simulations are carried out for casting of Al-33 wt.\% Cu strips having thickness of $2 \mathrm{~mm}$ in a twinroll caster at casting speed $0.7979 \mathrm{~m} / \mathrm{s}(100 \mathrm{rpm})$. Figure 5 shows the solidification profile of liquid Al-33 wt.\% $\mathrm{Cu}$ in the molten pool for different pouring temperatures. From the solidification profile it is observed that when the pouring temperature of the liquid metal is $831 \mathrm{~K}$, the thickness of the solidified shell is $0.29 \mathrm{~mm}$ and the thickness of the solidified shell is $0.08 \mathrm{~mm}$ at pouring temperature of $941 \mathrm{~K}$. Beyond $941 \mathrm{~K}$ the presence of solidified shell is not observed [68].

$\mathrm{Al}-\mathrm{Cu}$ eutectic alloy strip was prepared at different liquid melt superheat of $30 \mathrm{~K}-70 \mathrm{~K}$ (initial liquid metal temperature
$851 \mathrm{~K}$ to $921 \mathrm{~K}$ ) with casting speed $0.79 \mathrm{~m} / \mathrm{s}$. Figure 6 shows the microstructure of as-cast eutectic Al-Cu strip for different liquid melt superheat. From the microstructure it is observed that, at low liquid melt superheat, the strip microstructure consists of dark globular precipitates like flowery pattern within matrix of a eutectic structure. With increase in the liquid melt superheat, the flowery pattern increases and spreads throughout the surface of the strip. This is due to decrease in cooling rate, which also decreases the solidification growth velocity. As the superheat of the liquid metal increases, it will increase the temperature of the liquid metal in the molten pool by keeping all other parameters constant. When the liquid metal temperature increases, it will take more time to solidify. So, a variety of eutectic morphologies can be seen across the surface of the strip. This transition in the eutectic microstructure is considered to be due to the decrease in the local cooling rate and the solidification velocity [69].

\section{Conclusion}

Compared to conventional casting process, vertical twin-roll strip casting process is economical for production of thin 


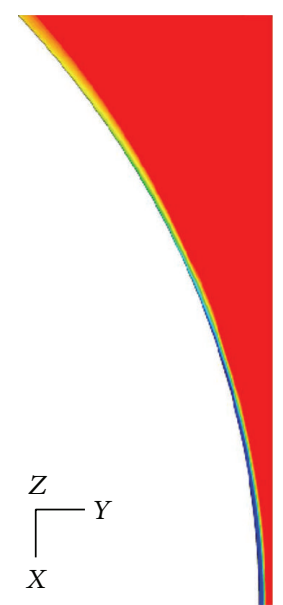

(a)

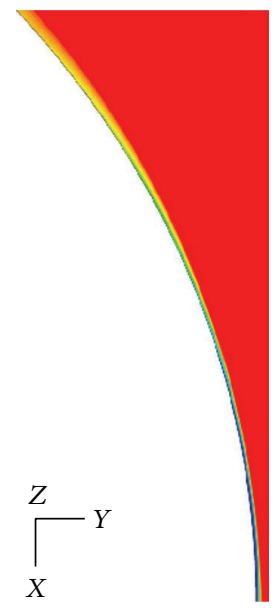

(d)

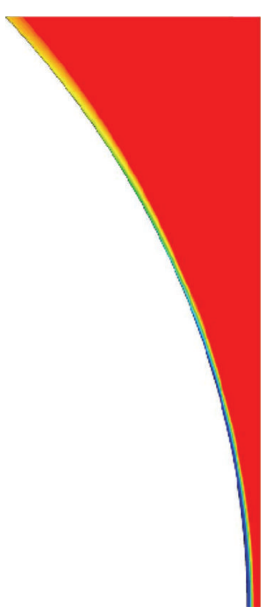

(b)

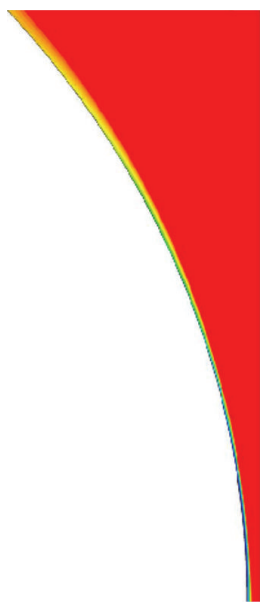

(e)

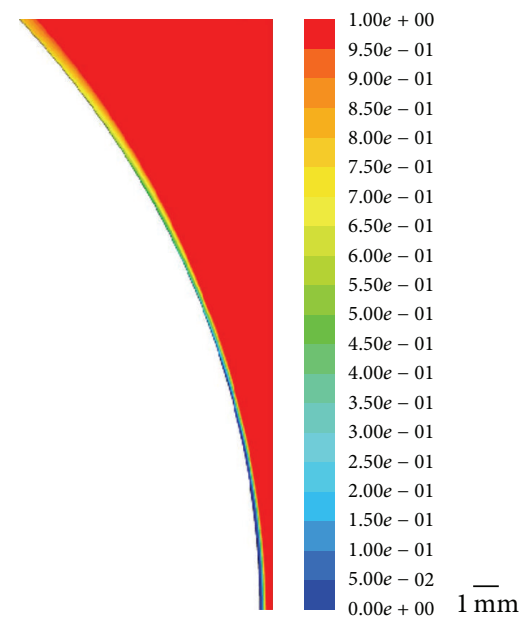

(c)

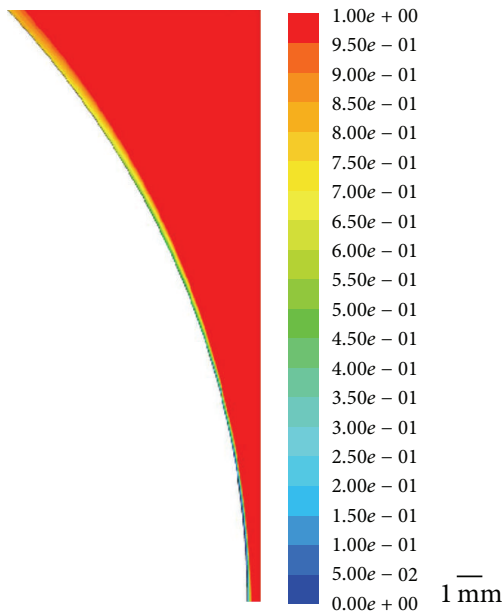

(f)

Figure 5: Solidification profile of Al-33Cu at different pouring temperatures: (a) $831 \mathrm{~K}$, (b) $851 \mathrm{~K}$, (c) $871 \mathrm{~K}$, (d) $891 \mathrm{~K}$, (e) $921 \mathrm{~K}$, and (f) $941 \mathrm{~K}$ (casting speed $0.79 \mathrm{~m} / \mathrm{s}$ ).

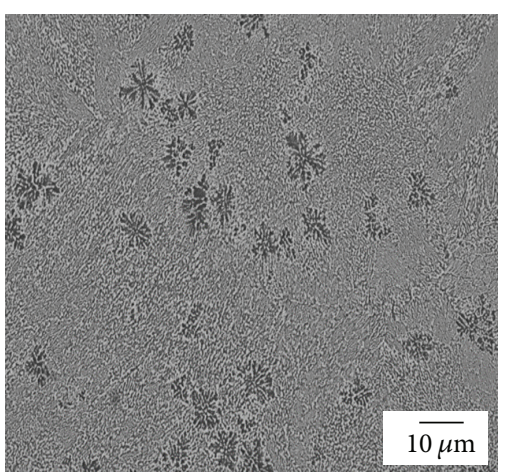

(a)

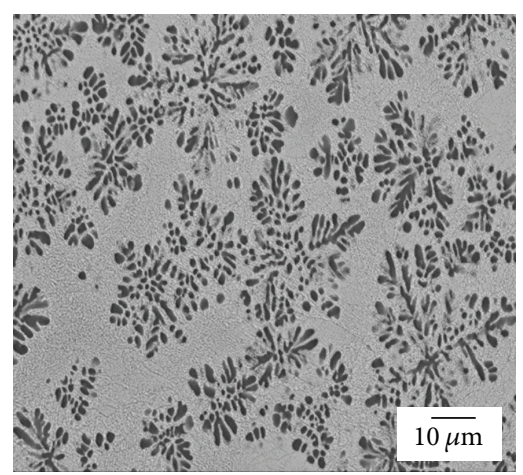

(b)

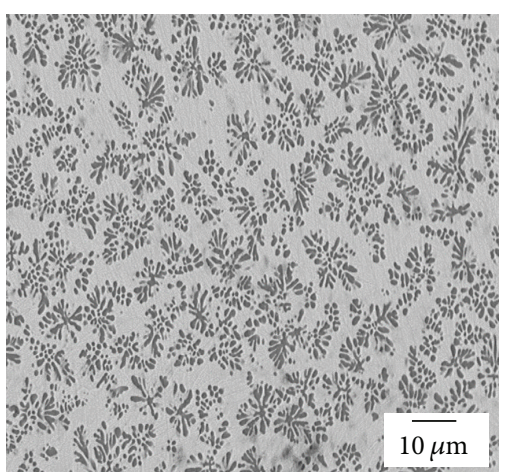

(c)

Figure 6: Microstructure of the eutectic Al-Cu strip at different liquid melt superheat: (a) $30 \mathrm{~K}$, (b) $50 \mathrm{~K}$, and (c) $70 \mathrm{~K}$ with $0.7979 \mathrm{~m} / \mathrm{s}$ casting speed. 
strips. This review briefly describes vertical twin-roll strip casting process and gives an idea about the effect of process parameters on solidification as well as the quality of the ascast strip. Although the extensive research work on twinroll strip casting process has been conducted over the last decade, there are still some important issues requiring further investigation.

(i) Due to the interaction of several complex phenomena like fluid flow, heat transfer, and solidification, comprehensive modeling of the high speed vertical twinroll strip casting is a challenging task.

(ii) The microstructure formed in the transient stage is expected to be different from that during the steady state condition. As a result of this, an initial portion of the strip needs to be rejected. Thus a comprehensive modeling of flow, heat transfer, and solidification during the transient state is required to estimate the length of the strip, thus possessing different microstructure.

(iii) Much work has been focused on understanding the defect formations in the strips during TRC; however not many attempts have been made to eliminate the internal defects, in particular, centerline segregation. Further work is necessary in this direction to extend the range of alloys that can be twin-roll cast with tolerable amount of segregation for a particular end application.

\section{Competing Interests}

The author declares that they have no competing interests.

\section{References}

[1] R. Wechsler, "The status of twin-roll casting technology," Scandinavian Journal of Metallurgy, vol. 32, no. 1, pp. 58-63, 2003.

[2] N. Zapuskalov, "Comparison of continuous strip casting with conventional technology," ISIJ International, vol. 43, no. 8, pp. 1115-1127, 2003.

[3] C. Gras, M. Meredith, and J. D. Hunt, "Microdefects formation during the twin-roll casting of Al-Mg-Mn aluminium alloys," Journal of Materials Processing Technology, vol. 167, no. 1, pp. 6272, 2005.

[4] H. Bessemer, "Improvement in the manufacture of iron and steel," U.S. Patent No. 49053, 1865.

[5] K. Shibuya and M. Ozawa, "Strip casting techniques for steel," ISIJ International, vol. 31, no. 7, pp. 661-668, 1991.

[6] A. L. Robson and G. L. Thompson, "Direct casting of thin strip," Materials World, vol. 3, no. 5, pp. 222-224, 1995.

[7] D.-K. Choo, S. Lee, H.-K. Moon, and T. Kang, "Analysis and prevention of cracking during strip casting of AISI 304 stainless steel," Metallurgical and Materials Transactions A, vol. 32, no. 9, pp. 2249-2258, 2001.

[8] M. Ha, J. Choi, S. Jeong, H. Moon, S. Lee, and T. Kang, "Analysis and prevention of microcracking phenomenon occurring during strip casting of an AISI 304 stainless steel," Metallurgical and Materials Transactions A, vol. 33, no. 5, pp. 1487-1497, 2002.
[9] M. Toshirou, N. Katsumi, F. Hisahiko, and O. Shirou, "Development and commercialization of twin roll strip caster," IHI Engineering Review, vol. 42, no. 1, pp. 1-9, 2009.

[10] J. Zeng, R. Koitzsch, H. Pfeifer, and B. Friedrich, "Numerical simulation of the twin-roll casting process of magnesium alloy strip," Journal of Materials Processing Technology, vol. 209, no. 5, pp. 2321-2328, 2009.

[11] T. Haga, K. Takahashi, M. Ikawa, and H. Watari, "A vertical-type twin roll caster for aluminum alloy strips," Journal of Materials Processing Technology, vol. 140, no. 1-3, pp. 610-615, 2003.

[12] R. P. Tavares and R. I. L. Guthrie, "Computational fluid dynamics applied to twin-roll casting," Canadian Metallurgical Quarterly, vol. 37, no. 3-4, pp. 241-250, 1998.

[13] T. Haga and S. Suzuki, "Study on high-speed twin-roll caster for aluminum alloys," Journal of Materials Processing Technology, vol. 143-144, no. 1, pp. 895-900, 2003.

[14] J. G. Lee, S. S. Park, S. B. Lee, H.-T. Chung, and N. J. Kim, "Sheet fabrication of bulk amorphous alloys by twin-roll strip casting," Scripta Materialia, vol. 53, no. 6, pp. 693-697, 2005.

[15] H.-S. Di, Y.-L. Li, Z.-L. Ning, Z. Li, X. Liu, and G.-D. Wang, "New processing technology of twin roll strip casting of AZ31B magnesium trip," Materials Science Forum, vol. 488-489, pp. 615-618, 2005.

[16] T. Haga and S. Suzuki, "A high speed twin roll caster for aluminum alloy strip," Journal of Materials Processing Technology, vol. 113, no. 1-3, pp. 291-295, 2001.

[17] S. Sahoo, A. Kumar, B. K. Dhindaw, and S. Ghosh, "High speed twin roll casting of aluminum-copper strips with layered structure," Materials and Manufacturing Processes, vol. 28, no. 1, pp. 61-65, 2013.

[18] H. Fiedler, M. Jurisch, P. Preiss et al., “Thin strip casting by a twin roller pilot plant," Materials Science and Engineering A, vol. 133, pp. 671-675, 1991.

[19] H. Yasunaka, K. Taniguchi, M. Kokita, and T. Inoue, "Surface quality of stainless steel type 304 cast by twin-roll type strip caster," ISIJ International, vol. 35, no. 6, pp. 784-789, 1995.

[20] M. Yukumoto and H. Yamane, "Thin strip casting of Ni base alloys by twin roll process," ISIJ International, vol. 35, no. 6, pp. 778-783, 1995.

[21] T. Haga, H. Sakaguchi, H. Watari, and S. Kumai, "High speed twin roll casting of 6061 alloy strips," Archives of Materials Science and Engineering, vol. 31, no. 1, pp. 49-52, 2008.

[22] H. Sakaguchi, T. Haga, H. Watari, and S. Kumai, "High speed twin roll casting of 6016 aluminum alloy strip," Jouranl of Achievements in Materials And Manufacturing Engineering, vol. 20, no. 1-2, pp. 495-498, 2007.

[23] K. Miyazawa and J. Szekely, "Mathematical-model of the splat cooling process using the twin-roll technique," Metallurgical Transactions A, vol. 12, no. 6, pp. 1047-1057, 1981.

[24] T. Saitoh, H. Hojo, H. Yaguchi, and C. G. Kang, "Twodimensional model for twin-roll continuous casting," Metallurgical Transactions B, vol. 20, no. 3, pp. 381-390, 1989.

[25] H. Murakami, M. Hasan, and R. I. L. Guithrie, "A mathematical model for avertical twin-roll caster," in Proceedings of the Process Technology Conference, vol. 10, pp. 347-354, Toronto, Canada, April 1992.

[26] S.-W. Lee, "A computer modelling of flowfield and solidification in rotating bank of twin-roll strip casting," Korean Journal of Chemical Engineering, vol. 10, no. 3, pp. 182-187, 1993.

[27] S. M. Hwang and Y. H. Kang, "Analysis of flow and heat transfer in twin-roll strip casting by finite element method," Journal of Engineering for Industry, vol. 117, no. 3, pp. 304-315, 1995. 
[28] S. H. Seyedein and M. Hasan, "Numerical simulation of turbulent flow and heat transfer in the wedge-shaped liquid metal pool of a twin-roll caster," Numerical Heat Transfer-Part A: Applications, vol. 31, no. 4, pp. 393-410, 1997.

[29] J.-G. Chang and C.-I. Weng, "Analysis of flow and heat transfer in twin-roll strip casting process," International Journal of Heat and Mass Transfer, vol. 41, no. 2, pp. 475-487, 1998.

[30] R. I. L. Guthrie and R. P. Tavares, "Mathematical and physical modelling of steel flow and solidification in twin-roll/horizontal belt thin-strip casting machines," Applied Mathematical Modelling, vol. 22, no. 11, pp. 851-872, 1998.

[31] C. A. Santos, J. A. Spim Jr., and A. Garcia, "Modeling of solidification in twin-roll strip casting," Journal of Materials Processing Technology, vol. 102, no. 1, pp. 33-39, 2000.

[32] M. Gupta and Y. Sahai, "Mathematical modeling of fluid flow, heat transfer, and solidification in two-roll melt drag thin strip casting of steel," ISIJ International, vol. 40, no. 2, pp. 144-152, 2000.

[33] W.-S. Kim, D.-S. Kim, and A. V. Kuznetsov, "Simulation of coupled turbulent flow and heat transfer in the wedge-shaped pool of a twin-roll strip casting process," International Journal of Heat and Mass Transfer, vol. 43, no. 20, pp. 3811-3822, 2000.

[34] D.-S. Kim, W.-S. Kim, and A. V. Kuznetsov, "Analysis of coupled turbulent flow and solidification in the wedge-shaped pool with different nozzles during twin-roll strip casting," Numerical Heat Transfer; Part A: Applications, vol. 41, no. 1, pp. 1-17, 2002.

[35] M. A. Cruchaga, D. J. Celentano, and R. W. Lewis, "Modelling of twin-roll strip casting processes," Communications in Numerical Methods in Engineering, vol. 19, no. 8, pp. 623-635, 2003.

[36] Y.-C. Miao, X.-M. Zhang, H.-S. Di, and G.-D. Wang, "Numerical simulation of the fluid flow, heat transfer, and solidification of twin-roll strip casting," Journal of Materials Processing Technology, vol. 174, no. 1-3, pp. 7-13, 2006.

[37] J. W. Bae, C. G. Kang, and S. B. Kang, "Mathematical model for the twin roll type strip continuous casting of magnesium alloy considering thermal flow phenomena," Journal of Materials Processing Technology, vol. 191, no. 1-3, pp. 251-255, 2007.

[38] G. M. Cao, C. G. Li, Z. Y. Liu, D. Wu, G. D. Wang, and X. H. Liu, "Numerical simulation of molten pool and control strategy of kiss point in a twin-roll strip casting process," Acta Metallurgica Sinica, vol. 21, no. 6, pp. 459-468, 2008.

[39] X. M. Zhang, Z. Y. Jiang, L. M. Yang, X. H. Liu, G. D. Wang, and A. K. Tieu, "Modelling of coupling flow and temperature fields in molten pool during twin-roll strip casting process," Journal of Materials Processing Technology, vol. 187-188, pp. 339-343, 2007.

[40] Y. Fang, Z.-M. Wang, Q.-X. Yang et al., "Numerical simulation of the temperature fields of stainless steel with different roller parameters during twin-roll strip casting," International Journal of Minerals, Metallurgy and Materials, vol. 16, no. 3, pp. 304-308, 2009.

[41] B. Wang, J.-Y. Zhang, J.-F. Fan, S.-L. Zhao, S.-B. Ren, and K.-C. Chou, "Modelling of melt flow and solidification in the twinroll strip casting process," Steel Research International, vol. 80, no. 3, pp. 218-222, 2009.

[42] H. Zhao, P. Li, and L. He, "Coupled analysis of temperature and flow during twin-roll casting of magnesium alloy strip," Journal of Materials Processing Technology, vol. 211, no. 6, pp. 1197-1202, 2011.

[43] Q. Li, Y. K. Zhang, L. G. Liu et al., "Effect of casting parameters on the freezing point position of the 304 stainless steel during twin-roll strip casting process by numerical simulation," Journal of Materials Science, vol. 47, no. 9, pp. 3953-3960, 2012.
[44] A. Hadadzadeh and M. A. Wells, "Mathematical modeling of thermo-mechanical behavior of strip during twin roll casting of an AZ31 magnesium alloy," Journal of Magnesium and Alloys, vol. 1, no. 2, pp. 101-114, 2013.

[45] C. Shoudong and C. Jingchao, "Micromodel of simulation on twin-roll continuous casting od thin strip solidification structure," Rare Metal Materials and Engineering, vol. 42, no. 1, pp. $14-18,2013$.

[46] A. Hadadzadeh, M. A. Wells, and I.-H. Jung, "Scale-up modeling of the twin roll casting process for AZ31 magnesium alloy," Journal of Manufacturing Processes, vol. 16, no. 4, pp. 468-478, 2015.

[47] S. Sahoo, A. Kumar, B. K. Dhindaw, and S. Ghosh, "Modeling and experimental validation of rapid cooling and solidification during high-speed twin-roll strip casting of Al-33 wt pct $\mathrm{Cu}$," Metallurgical and Materials Transactions B, vol. 43, no. 4, pp. 915-924, 2012.

[48] S. Sahoo and S. Ghosh, "Heat transfer, solidification, and microstructural evolution in al-33Cu alloy during the starting of twin roll strip casting," Steel Research International, vol. 85, no. 2, pp. 207-218, 2014.

[49] Y.-S. Lee, H.-W. Kim, and J.-H. Cho, "Process parameters and roll separation force in horizontal twin roll casting of aluminum alloys," Journal of Materials Processing Technology, vol. 218, pp. 48-56, 2015.

[50] J.-J. Park, "Numerical analyses of cladding processes by twinroll casting: Mg-AZ31 with aluminum alloys," International Journal of Heat and Mass Transfer, vol. 93, pp. 491-499, 2016.

[51] K. Shibuya, F. Kogiku, M. Yukumoto, S. Miyake, M. Ozawa, and T. Kan, "Development of a rapid solidification process with a double-roller method," Materials Science and Engineering, vol. 98, pp. 25-28, 1988.

[52] R. Cook, P. G. Grocock, P. M. Thomas, D. V. Edmonds, and J. D. Hunt, "Development of the twin-roll casting process," Journal of Materials Processing Technology, vol. 55, no. 2, pp. 76-84, 1995.

[53] N. Zapuskalov and M. Vereschagin, "Effect of technological factors on strip profile in twin-roll casting process," ISIJ International, vol. 38, no. 10, pp. 1107-1113, 1998.

[54] F.-X. Huang, X.-H. Wang, and W.-J. Wang, "Microstructures of austenitic stainless steel produced by twin-roll strip caster," Journal of Iron and Steel Research International, vol. 19, no. 2, pp. 57-61, 2012.

[55] S. Das, N. S. Lim, H. W. Kim, and C. G. Park, "Effect of rolling speed on microstructure and age-hardening behaviour of Al$\mathrm{Mg}$-Si alloy produced by twin roll casting process," Materials and Design, vol. 32, no. 8-9, pp. 4603-4607, 2011.

[56] B. Jiang, W. Liu, D. Qiu, M.-X. Zhang, and F. Pan, "Grain refinement of $\mathrm{Ca}$ addition in a twin-roll-cast Mg-3Al-1Zn alloy," Materials Chemistry and Physics, vol. 133, no. 2-3, pp. 611-616, 2012.

[57] S. Das, N. S. Barekar, O. El Fakir et al., "Effect of melt conditioning on heat treatment and mechanical properties of AZ31 alloy strips produced by twin roll casting," Materials Science and Engineering A, vol. 620, pp. 223-232, 2014.

[58] H. Wang, L. Zhou, Y. Zhang, Y. Cai, and J. Zhang, "Effects of twin-roll casting process parameters on the microstructure and sheet metal forming behavior of 7050 aluminum alloy," Journal of Materials Processing Technology, vol. 233, pp. 186-191, 2016.

[59] R. Nakamura, T. Haga, S. Kumai, and H. Watari, "Casting of aluminum alloy clad strip using a vertical type tandem twin roll caster," Advanced Materials Research, vol. 97-101, pp. 1053-1056, 2010. 
[60] K. Neh, M. Ullmann, M. Oswald, F. Berge, and R. Kawalla, "Twin roll casting and strip rolling of several magnesium alloys," Materials Today: Proceedings, vol. 2, supplement 1, pp. S45-S52, 2015.

[61] M. Chen, X.-D. Hu, B. Han, X.-H. Deng, and D.-Y. Ju, "Study on the microstructural evolution of AZ31 magnesium alloy in a vertical twin-roll casting process," Applied Physics A: Materials Science and Processing, vol. 122, no. 2, pp. 1-10, 2016.

[62] B. Forbord, B. Andersson, F. Ingvaldsen, O. Austevik, J. A. Horst, and I. Skauvik, "The formation of surface segregates during twin roll casting of aluminium alloys," Materials Science and Engineering A, vol. 415, no. 1-2, pp. 12-20, 2006.

[63] J. D. Hwang, H. J. Lin, J. S. C. Jang, W. S. Hwang, and C. T. Hu, "Relationship between flow characteristics and surface quality in inclined twin roll strip casting," ISIJ International, vol. 36, no. 6, pp. 690-699, 1996.

[64] T. Mizoguchi, K.-I. Miyazawa, and Y. Ueshima, "Relation between surface quality of cast strips and meniscus profile of molten pool in the twin roll casting process," ISIJ International, vol. 36, no. 4, pp. 417-423, 1996.

[65] S. A. Lockyer, M. Yun, J. D. Hunt, and D. V. Edmonds, "Microand macrodefects in thin sheet twin-roll cast aluminum alloys," Materials Characterization, vol. 37, no. 5, pp. 301-310, 1996.

[66] D. J. Monaghan, M. B. Henderson, J. D. Hunt, and D. V. Edmonds, "Microstructural defects in high productivity twinroll casting of aluminium," Materials Science and Engineering A, vol. 173, no. 1-2, pp. 251-254, 1993.

[67] M. Yun, S. Lokyer, and J. D. Hunt, "Twin roll casting of aluminium alloys," Materials Science and Engineering A, vol. 280, no. 1, pp. 116-123, 2000.

[68] S. Sahoo, "Effect of process parameters on solidification of Al$33 \mathrm{Cu}$ strip in high speed twin roll strip casting- A numerical study," IOP Conference Series Materials Science and Engineering, vol. 75, no. 1, Article ID 012013, 2015.

[69] S. Sahoo and S. Ghosh, "Microstructure evolution of eutectic $\mathrm{Al}-\mathrm{Cu}$ strips by high-speed twin-roll strip casting process," Applied Physics A, vol. 121, no. 1, pp. 45-50, 2015. 

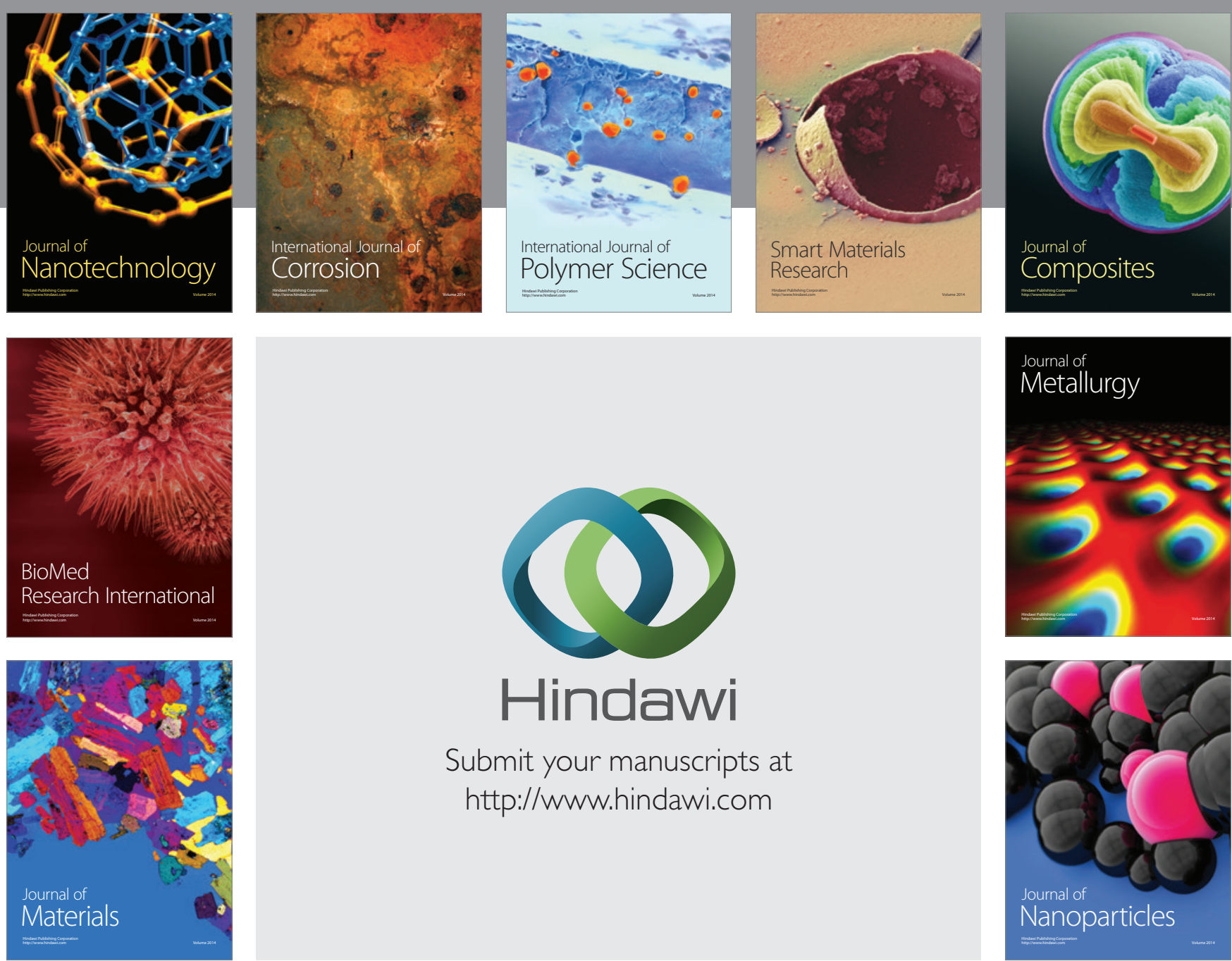

\section{Hindawi}

Submit your manuscripts at

http://www.hindawi.com

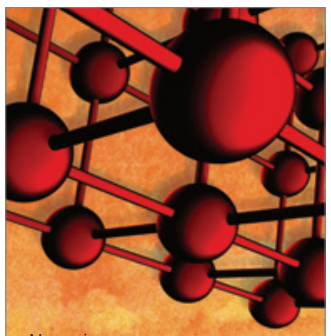

Materials Science and Engineering
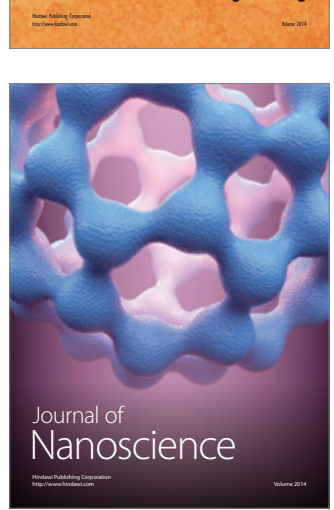
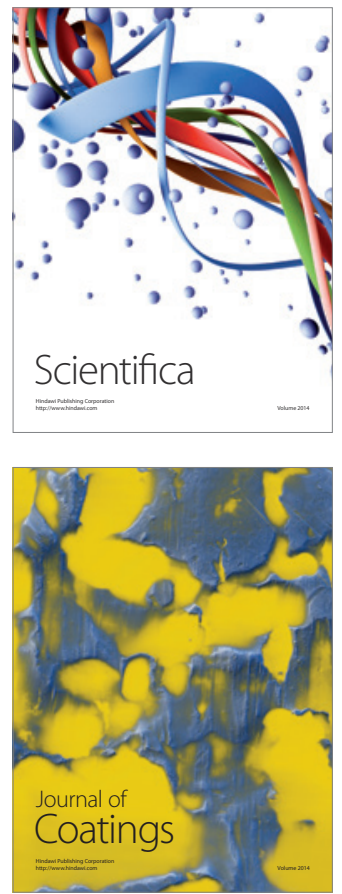
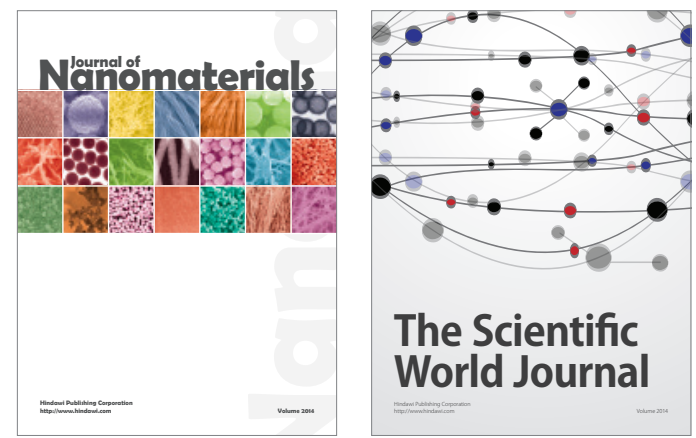

The Scientific World Journal
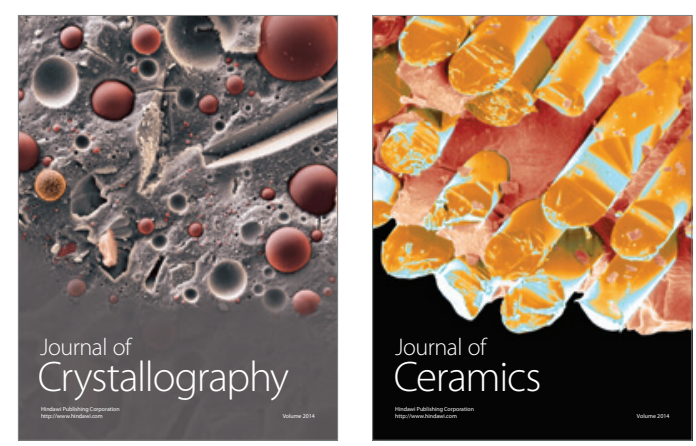
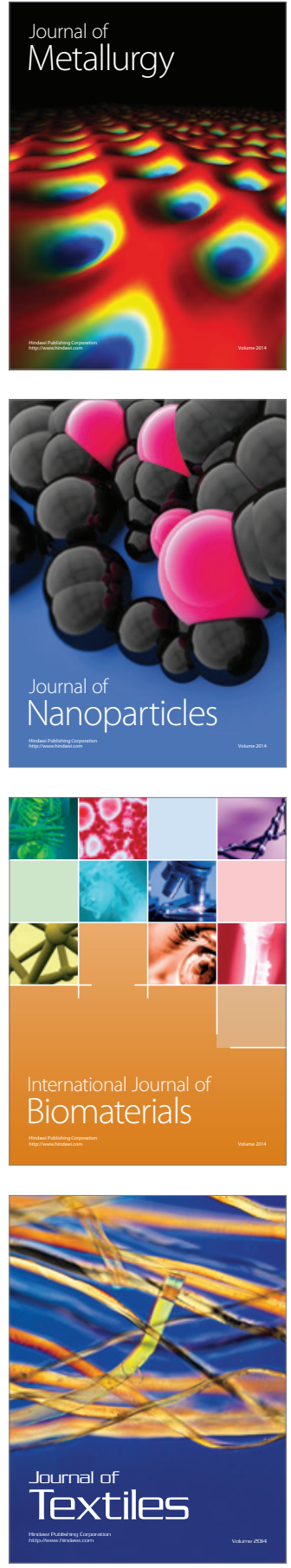